\title{
Analysis of the Leeb Hardness Test Data Obtained by Using Two Different Rock Core Holders
}

\author{
Nurdan GÜNEŞ YILMAZ*1, R. Mete GÖKTAN² \\ ${ }^{1}$ Dokuz Eylul University, Torbalı Vocational School, Natural Building Stone Technology Program, 35860, İzmir \\ ${ }^{2}$ Eskișehir Osmangazi University, Engineering Faculty, Mining Engineering Department, 26040, Eskișehir
}

(Alınıș / Received: 29.05.2017, Kabul / Accepted: 27.10.2017, Online Yayınlanma / Published Online: 03.01.2018)

\section{Keywords}

Core holder,

Equotip hardness tester, Leeb hardness,

Uniaxial compressive strength, Rebound hardness

\begin{abstract}
In this study, an investigation was carried out to elucidate if the core holder type affects the measured Leeb hardness values (HL) of rock materials obtained by using the Equotip hardness tester. To achieve this goal, NX-size core specimens of different rock samples were subjected to Leeb hardness testing by employing an 'Arch-shaped' and a 'V-shaped' core holder. The results indicated a strong degree of linear correlation $\left(\mathrm{R}^{2} \cong 0.95\right)$ between mean rebound hardness values determined in the arch-shaped holder $\left(\mathrm{HL}_{\mathrm{A}}\right)$ and $\mathrm{V}$-shaped holder $\left(\mathrm{HLV}_{\mathrm{V}}\right)$. The maximum difference in HL values obtained from the two holders was 74.2 units on the HL-scale, corresponding to a difference of $10.2 \%$. Although the differences in magnitudes of $\mathrm{HL}_{\mathrm{A}}$ and $\mathrm{HL} v$ values were small and varied from one rock variety to another, there was a tendency of the $\mathrm{V}$-shaped holder to give relatively lower values. On the other hand, when compared to the minimum values, a higher statistical correspondence was observed between maximum $\mathrm{HL}_{\mathrm{A}}$ and $\mathrm{HLV}$ values. The results also showed that it is possible to predict uniaxial compressive strength of the tested rocks reliably by employing any of the holders.
\end{abstract}

\section{İki Farklı Karot Beşiği Kullanılarak Elde Edilen Leeb Sertlik Deneyi Verilerinin Analizi}

\author{
Anahtar Kelimeler \\ Karot beşiği, \\ Equotip sertlik cihazl, \\ Leeb sertliği, \\ Tek eksenli basma dayanımı, \\ Geri sıçrama sertliği
}

\begin{abstract}
Özet: $\mathrm{Bu}$ çalışmada, Equotip sertlik cihazı kullanılarak ölçülen kaya malzemesi Leeb sertliği (HL) değerlerinin karot beşiği türüne göre değişiklik gösterip göstermediği araştırılmıştır. Bu amaçla, farklı kayaçlara ait NX-boyutlu karot deney örnekleri 'Kavis-biçimli' ve 'V-biçimli' beşikler üzerinde Leeb sertliği deneylerine tabi tutulmuştur. Sonuçlar, kavis-biçimli $\left(\mathrm{HL}_{\mathrm{A}}\right)$ ve V-biçimli $\left(\mathrm{HL}_{\mathrm{V}}\right)$ beşiklerden elden edilen ortalama geri sıçrama sertlik değerleri arasında kuvvetli bir doğrusal ilişki $\left(\mathrm{R}^{2} \cong 0.95\right.$ ) bulunduğunu göstermiştir. İki beşikten elde edilen HL değerleri arasındaki en yüksek fark HL-ölçeğinde 74,2 birim olup \% 10,2'lik bir farklılığa karşılık gelmektedir. $\mathrm{HL}_{\mathrm{A}}$ ve $\mathrm{HL}_{\mathrm{V}}$ değerleri arasındaki farklılıkların az olmasına ve kayaç türüne göre değişiklik göstermesine rağmen, V-biçimli beșiğin görece daha küçük değerler verme eğilimi gösterdiği belirlenmiştir. Diğer yandan, minimum değerlerlerle karşılaştırıldığında, maksimum $\mathrm{HL}_{\mathrm{A}}$ ve $\mathrm{HL}_{\mathrm{V}}$ değerleri arasında daha yüksek bir istatistiksel ilişki bulunduğu gözlenmiştir. Sonuçlar ayrıca, deneyleri yapılan kayaçların tek eksenli basma dayanımı kestiriminde her iki beşiğin de güvenilir bir şekilde kullanılabileceğini göstermiştir.
\end{abstract}

\section{Introduction}

Non-destructive dynamic rebound hardness tests such as the Shore scleroscope hardness and Schmidt hammer hardness are the widely used index tests in the general field of rock engineering. However, these two instruments are not without their limitations in practical applications. The Shore scleroscope is essentially a bench-top laboratory tool which is not convenient for field applications. Although the
Schmidt hammer can be used both in the field and laboratory, due to its high impact energy, it is not appropriate for the testing of weak or friable rock materials $[1,2]$. As will be described in the following, the Equotip hardness tester (EHT), however, is a relatively new instrument which has the potential of removing the afore-mentioned deficiencies of the Shore scleroscope and Schmidt hammer encountered in some practical applications. In this respect, the 
EHT is becoming a popular method for rock testing as well as weathering research [3].

The EHT is a portable, electronic battery-operated and non-destructive instrument which was initially developed to determine the dynamic hardness of metallic materials. The instrument was introduced in 1975 by the Swiss engineer Dietmar Leeb, and since then, it has also been used for the hardness determination and indirect strength estimation of rock materials. Testing with this instrument is based on the principle of energy measurement. An impact body with a hard tip is impacted by spring energy against the sample surface to be tested. During the impact, a permanent magnet integrated in the impact body passes through a coil in which voltage is induced by the forwards and backwards movement. This voltage is proportional to the velocity. To minimize the gravitational and frictional effects, the impact and rebound velocity are measured when the tip is approximately $1 \mathrm{~mm}$ away from the sample surface. The ratio of the rebound velocity $V_{r}$ to the impact velocity $V_{i}$ multiplied by 1000 yields the Leeb Hardness value HL [4]:

$$
H L=\left(V_{r} / V_{i}\right) 1000
$$

The harder the tested material, the higher is the rebound value. Due to its automatic compensation for impact direction, the instrument can be used in the field or laboratory at any angle [5,6]. Several impact devices (probes) can be used with the EHT. The impact energy of the standard type (type-D) is 11 $\mathrm{Nmm}$. Impact devices with impact energies of $3 \mathrm{Nmm}$ (type-C) and $90 \mathrm{Nmm}$ (type-G) are also available [7].

The relatively low impact energy of this instrument makes it applicable to weathered rocks as well as fresh rocks [2]. The EHT has been found applicable to rocks in the range of 5 to $280 \mathrm{MPa}$ uniaxial compressive strength [8], and hence, is considered as suitable for application across a wider range of rock hardness than the Schmidt hammer $[2,9]$. Due to its certain advantages over the traditional rebound hardness testing devices, several applications of EHT have emerged in rock engineering since early 1990s. As has been the case with the Shore scleroscope and Schmidt hammer, the use of this instrument is mainly for the preliminary estimation of rock UCS [7, 8, 1014]. Other major specific applications of the EHT that can be mentioned are the determination of discontinuity wall strength [6], rock characterization for construction materials and aggregates [15], weathering and deterioration assessment of rock surfaces [2, 3, 5], and determinations of the relations between Equotip hardness index, Shore index, drilling rate index, and other mechanical properties [16].

As quoted by Wilhelm et al. [3], despite its increasing popularity in the field of rock characterization, at present there is no consensus on methodology for the use of Equotip instrument in the field or laboratory, as well as the evaluation of the data obtained. Over the years, various aspects of Equotip hardness testing have been studied by different authors. These topics generally include the influence of recording techniques [2, 11, 12, 17], optimum number of readings to be taken $[3,5]$, stone and operator variance $[3,5]$, block size and edge effects $[5,11]$, and the effect of moisture and surface roughness [5].

The possibility to perform rebound hardness measurements on even weak rocks makes the Equotip instrument very useful for core logging [7]. In rebound testing of rock cores, to remove the influence of background material during the test, it is necessary to seat the core specimens firmly on a steel core holder, also referred to as "cradle block". In the core logging practice, an 'Arch-shaped' or a 'V-shaped' core holder is used for this purpose (Figure 1).

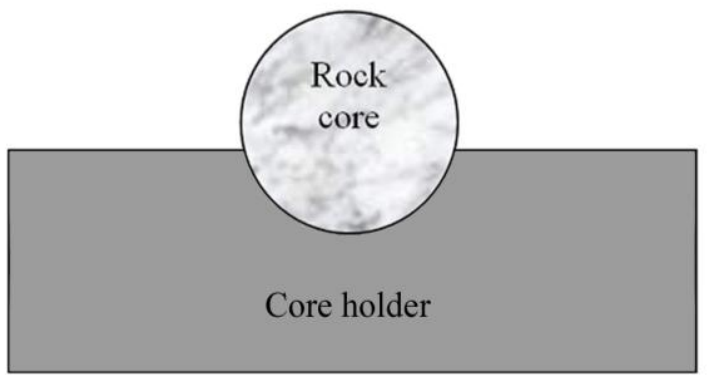

(a)

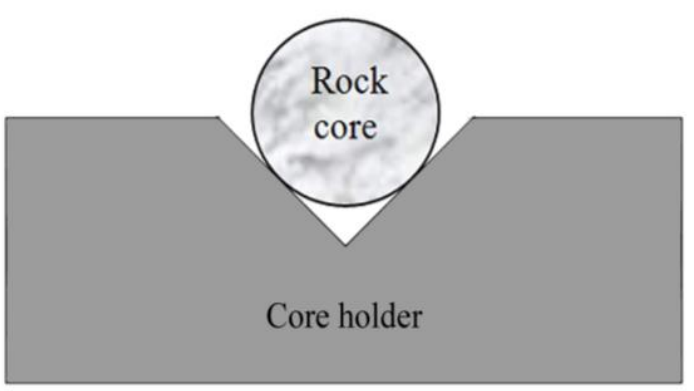

(b)

Figure 1. The arc-shaped (a) and V-shaped (b) core holder

The influence of core holder type on rebound readings was previously investigated for Schmidt hammer testing $[18,19]$. The results of these studies have indicated that the rebound values could be influenced to some extent by the geometry of the employed core holder. So far as the present authors are aware, the potential influence of core holder type on Leeb Hardness (HL) values has not been the subject of any previous study. In this respect, it is not known yet whether the HL values determined from core holders of different geometry are equally influenced by the hardness variations on rock surfaces. Considering this fact, the present study was undertaken to investigate the potential influence of holder type on the obtained HL values. To achieve this goal, core specimens belonging to different rock samples were subjected to Leeb hardness testing using the arch and V-shaped holders. The obtained 
test data were statistically evaluated and analytical interpretations of the findings were made. Also, as a secondary topic, the influence of some physicomechanical rock properties on HL values was examined.

\section{Material and Method}

The Leeb hardness tests were performed on NX-size (54 mm diameter) core specimens of 16 different rock samples that were available in the laboratory, belonging to previous works. To characterize the physico-mechanical properties of the tested rock samples, apparent density $(d)$, open porosity $(p)$, and uniaxial compressive strength (UCS) values were determined. For the density and porosity determinations, test procedures specified in the TS EN 1936 Standard [20] was followed, while the procedure suggested by the ISRM [21] was adopted for the uniaxial compressive strength determinations. The results of the physico-mechanical tests are given in Table 1.

Using the Model Equotip 3 tester (with type-D impact device), core specimens of the rock samples were subjected to Leeb Hardness testing by employing the arch-shaped and V-shaped holders (Figure 2). To be able to make a more precise comparison, the same core specimen was used in both holders. For this purpose, the procedure relevant to Schmidt hammer testing and described in a previous study [19] was followed. In the first step, the circular face of any core specimen to be tested was labeled at $45^{\circ}$ increments and eight straight parallel lines were drawn along its longitudinal axis. Thereafter, rebound tests were performed by placing the core specimen in one of the holders and impacting the diamond tip of the instrument vertically along its longitudinal axis. In this way five readings were made at equal spacing. By rotating the core axis $90^{\circ}$ at a time, a total of 20 readings were obtained in one holder. Thereafter, to achieve comparable results, the same core specimen was placed in the other holder and the same measurement procedure was repeated. In this case, however, a separate set of $90^{\circ}$ rotations was employed to avoid any repeated impacts at a point. The average of 20 single impact readings was accepted as the mean rebound value for any series of tests. In this study, the rebound hardness values measured in the arc-shaped and V-shaped core holders will be referred as ' $\mathrm{HL}_{\mathrm{A}}$ ' and ' $\mathrm{HLV}$ ', respectively. To be used in the statistical analyzes the mean (arithmetic average), standard deviation, minimum and maximum, and median of $20 \mathrm{HL}$ readings recorded for each individual rock sample were calculated (Table 2).

\section{Results}

In this section of the study, two main issues will be addressed: Firstly, by performing correlation and regression analyses, the relations between Leeb hardness values (HL) obtained from the arch- shaped $\left(\mathrm{HL}_{\mathrm{A}}\right)$ and $\mathrm{V}$-shaped $\left(\mathrm{HL}_{\mathrm{V}}\right)$ core holders will be investigated. Secondly, the relation of the obtained $\mathrm{HL}_{\mathrm{A}}$ and $\mathrm{HLV}$ values to the physico-mechanical rock properties will be examined. In the analyses, the coefficient of determination $\left(\mathrm{R}^{2}\right)$ was used to examine the strength of the relation between the examined variables. The $\mathrm{R}^{2}$ is the proportion of variance in the dependent variable, which can be predicted from the independent variable. Higher values of $\mathrm{R}^{2}$ correspond to a stronger relation between the dependent and independent variables.

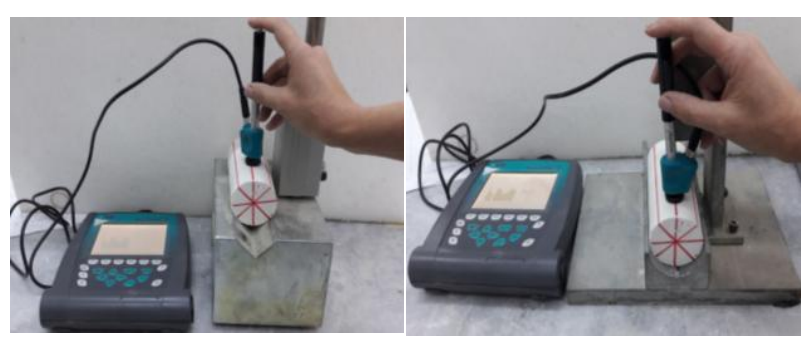

(a)

(b)

Figure 2. Testing of the core specimens with the arcshaped (a) and V-shaped (b) holders

Table 1. Physico-mechanical properties of the tested rock samples

\begin{tabular}{lllll}
$\begin{array}{c}\text { Sample } \\
\text { No. }\end{array}$ & \multicolumn{1}{c}{ Rock type } & $\begin{array}{c}\text { Apparent density } \\
\mathrm{d}\left(\mathrm{g} / \mathrm{cm}^{3}\right)\end{array}$ & $\begin{array}{c}\text { Open porosity } \\
\mathrm{p}(\%)\end{array}$ & $\begin{array}{c}\text { Uniaxial compressive } \\
\text { strength UCS }(\mathrm{MPa})\end{array}$ \\
\hline 1 & Slightly altered basalt & 2.82 & 0.10 & 94.0 \\
2 & Micritic limestone & 2.71 & 0.06 & 59.5 \\
3 & Andesite & 2.57 & 1.11 & 103.4 \\
4 & Kaolinized dacitic tuff & 1.58 & 24.48 & 11.1 \\
5 & Andesitic tuff & 2.39 & 4.05 & 29.0 \\
6 & Dacitic lithic tuff & 1.94 & 19.60 & 42.1 \\
7 & Lithic tuff & 2.08 & 13.95 & 65.0 \\
8 & Micritic limestone & 2.67 & 0.43 & 78.0 \\
9 & Dacitic lithic tuff & 1.94 & 17.74 & 42.8 \\
10 & Altered lithic tuff & 2.07 & 13.98 & 10.1 \\
11 & Agglomerate & 1.89 & 20.89 & 9.9 \\
12 & Travertine & 2.45 & 2.34 & 26.2 \\
13 & Partly altered andesite & 2.35 & 5.95 & 80.6 \\
14 & Partly altered basalt & 2.27 & 12.56 & 65.6 \\
15 & Limestone & 2.71 & 0.13 & 37.6 \\
16 & Marble & 2.75 & 0.33 & 65.5 \\
\hline
\end{tabular}


Table 2. Results of Leeb hardness tests

\begin{tabular}{lccccccccccccc}
\hline \multicolumn{1}{c}{ Sample no } & \multicolumn{4}{c}{ Arch-shaped core holder } & \multicolumn{4}{c}{ V-shaped core holder } \\
\hline & Mean & Max & Min & \multicolumn{1}{c}{ Std } & CoV & Median & Mean & Max & Min & Std & CoV & Median \\
1 & 866.2 & 903 & 825 & 20.6 & 2.38 & 865.0 & 862.2 & 885 & 831 & 15.5 & 1.80 & 867.0 \\
2 & 682.8 & 724 & 621 & 22.5 & 3.30 & 686.5 & 690.3 & 722 & 633 & 23.1 & 3.35 & 691.5 \\
3 & 748.7 & 837 & 554 & 68.6 & 9.16 & 744.5 & 754.6 & 809 & 643 & 49.5 & 6.62 & 768.0 \\
4 & 472.2 & 529 & 407 & 29.4 & 6.23 & 474.0 & 476.8 & 536 & 426 & 28.5 & 5.98 & 470.0 \\
5 & 593.4 & 675 & 473 & 54.4 & 9.16 & 609.5 & 566.5 & 630 & 448 & 57.0 & 10.06 & 578.5 \\
6 & 558.2 & 611 & 482 & 37.8 & 6.78 & 571.0 & 536.5 & 575 & 465 & 31.8 & 5.93 & 547.5 \\
7 & 562.1 & 680 & 305 & 112 & 20.10 & 588.0 & 568.5 & 671 & 428 & 79.0 & 13.90 & 557.0 \\
8 & 674.5 & 737 & 401 & 71.7 & 10.63 & 693.0 & 690.8 & 726 & 603 & 32.5 & 4.71 & 696.5 \\
9 & 550.6 & 616 & 406 & 53.8 & 9.78 & 562.5 & 546.2 & 708 & 392 & 76.3 & 13.97 & 568.5 \\
10 & 429.2 & 472 & 362 & 31.6 & 7.37 & 429.5 & 426.8 & 475 & 331 & 35.0 & 8.19 & 432.0 \\
11 & 426.9 & 634 & 222 & 120.1 & 28.12 & 430.0 & 477.1 & 717 & 198 & 126.8 & 26.57 & 440.5 \\
12 & 527.7 & 610 & 218 & 100.5 & 19.04 & 562.0 & 511.9 & 609 & 203 & 111.3 & 21.78 & 554.0 \\
13 & 724.8 & 801 & 586 & 50.9 & 7.03 & 736.5 & 650.6 & 756 & 370 & 97.4 & 14.98 & 677.0 \\
14 & 715.8 & 786 & 494 & 59.6 & 8.33 & 730.0 & 695.1 & 741 & 598 & 34.1 & 4.91 & 700.5 \\
15 & 548.2 & 640 & 439 & 49.7 & 9.07 & 553.5 & 558.5 & 635 & 480 & 42.8 & 7.66 & 569.5 \\
16 & 647.9 & 690 & 607 & 20.4 & 3.15 & 640.5 & 617.1 & 663 & 550 & 31.3 & 5.07 & 625.0 \\
\hline
\end{tabular}

Std: Standard deviation; CoV: Coefficient of variation (\%)

\subsection{Correlations between $H L_{A}$ and $H L_{V}$ values}

When the mean HL values are considered, the relation between $\mathrm{HL}_{\mathrm{A}}$ and $\mathrm{HL}_{V}$ values is plotted in Figure 3. In this case, the best fitted relation is found to be represented by a straight-line regression curve. This relation is expressed as:

$$
H L_{V}=0.9208 H L_{A}+41.807
$$

The above established regression equation, indicates that there is a strong degree of positive linear correlation $\left(\mathrm{R}^{2} \cong 0.95\right)$ between HL values obtained from the two holders. This observation suggests that the two holders have affected the HL values in similar ways. However, the slope of the regression line in Equation 2 indicates that for every 1-unit increase in $\mathrm{HL}_{\mathrm{A}}$, the value of $\mathrm{HL}_{\mathrm{V}}$ increases by 0.9208 . This implies that, despite the exceptions, the HL values measured in the V-shaped holder were generally lower than those of the arch-shaped holder. This might be due to the fact that the V-shaped holder leaves the specimen 'unsupported' directly below the impact point [1]. In other words, unlike the archshaped holder, the support provided to the core by the $\mathrm{V}$-shaped holder is at the sides only, not directly below the impact point (Figure 1). This may cause some impact energy dissipation during the strike of the diamond tip, resulting with relatively lower rebound values.

The maximum difference in HL values obtained from the two holders was 74.2 units on the HL-scale, corresponding to a difference of $10.2 \%$. On the other hand, the minimum difference was observed in Sample 10 with 2.3 units on the HL-scale, indicating a difference of $0.5 \%$. Here it is logical to state that the diverse geometrical shapes of the two holders, as well as random nature of the potential surface and inner inhomogeneities present in the core specimens might have affected the test results.

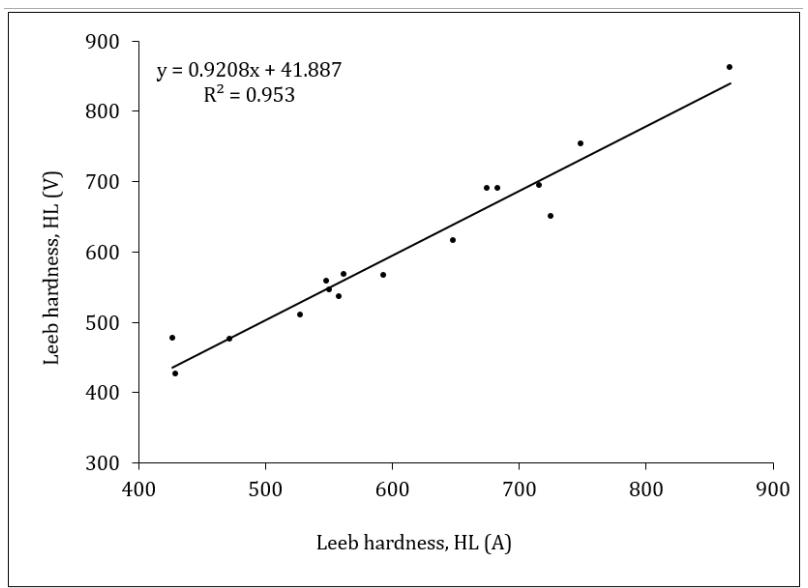

Figure 3. Relation between $\mathrm{HL}_{\mathrm{A}}$ and $\mathrm{HLv}$ using the mean values

When the maximum and minimum $\mathrm{HL}$ values illustrated in Table 2 are evaluated, it is seen from Figure 4 that there is a higher statistical correspondence between $\mathrm{HL}_{\mathrm{A}}$ and $\mathrm{HLV}$ in maximum values $\left(R^{2}=0.87\right)$ compared to minimum values $\left(R^{2}=\right.$ $0.70)$. This observation indicates that the statistical correlation between rebound values obtained in the two holders is also sensitive to the degree of hardness of the tested material.

In the case of median HL values illustrated in Table 2, the relation between $\mathrm{HL}_{\mathrm{A}}$ and $\mathrm{HL}_{\mathrm{V}}$ is plotted in Figure 5 , which is expressed by the regression model:

$$
H L_{V}=0.9671 H L_{A}+11.982 \quad\left(\mathrm{R}^{2} \cong 0.97\right)
$$

Comparison of the test statistics of Equations 2 and 3 indicates that the significance of the correlation between HL values obtained in the arc and V-shaped cradles has slightly improved when median values are employed in the regression analysis instead of the mean values. This is probably due to the fact that the median is not affected by the potential outliers in a 
data set, and therefore, is a more robust measure of central tendency [3]. It is known that outliers are the extreme values that can largely influence the arithmetic mean and the standard deviation of a data set.

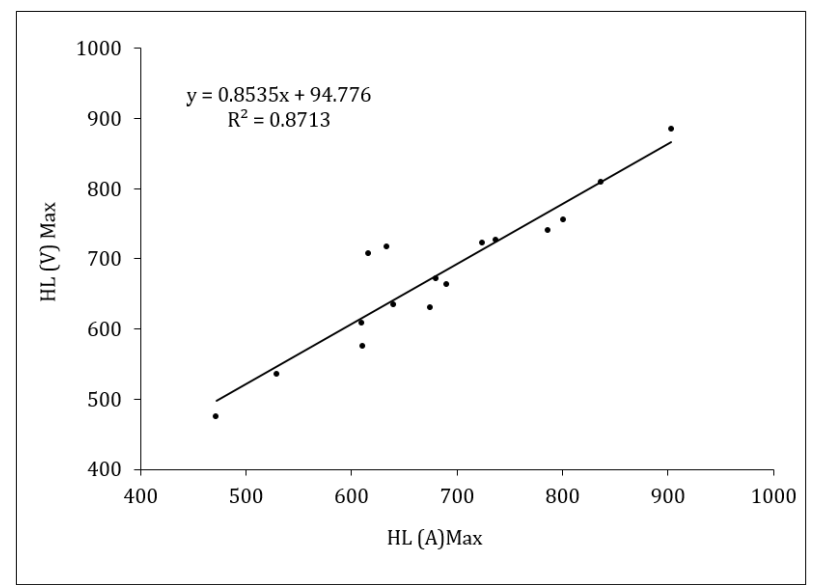

(a)

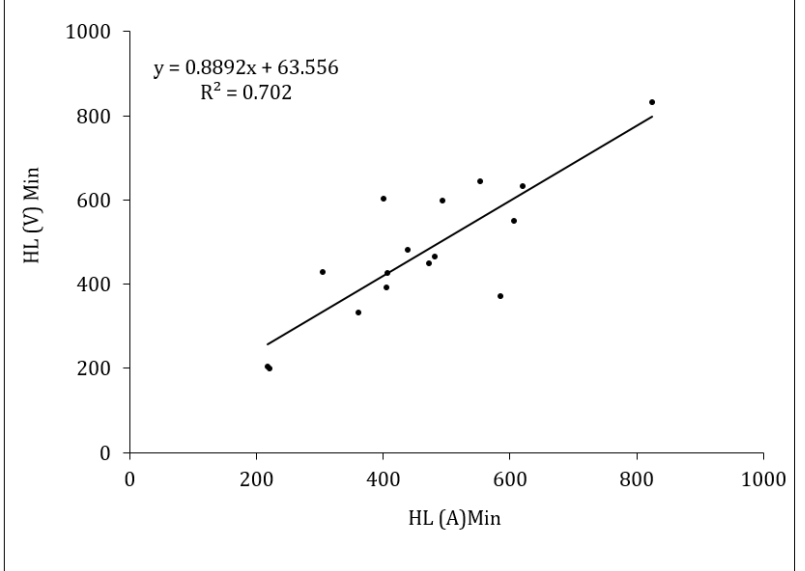

(b)

Figure 4. Relations between $\mathrm{HL}_{\mathrm{A}}$ and $\mathrm{HLv}$ using the maximum (a) and minimum (b) values

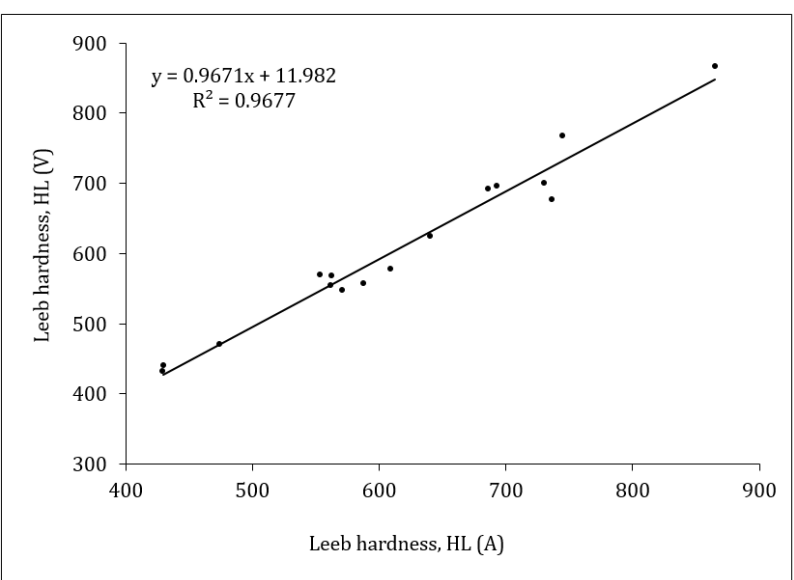

Figure 5. Relation between $\mathrm{HL}_{\mathrm{A}}$ and $\mathrm{HLv}$ using the median values

\subsubsection{Comparison of variability}

An important disadvantage of the Equotip hardness tester is that the small diameter $(3 \mathrm{~mm})$ diamond tipped impact body of the instrument makes it highly sensitive to local inhomogeneities on the surface/near surface of the rock, resulting with large variations in the measured hardness values. One representative example of the typical variations recorded during a series of tests is illustrated in Figure 6. It is seen that the measured rebound values in both core holders are not consistent and exhibit considerable fluctuations.

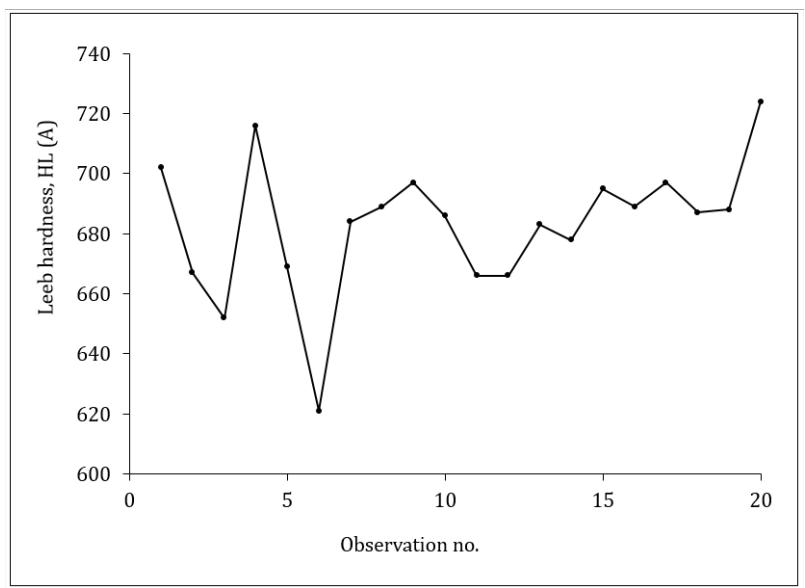

(a)

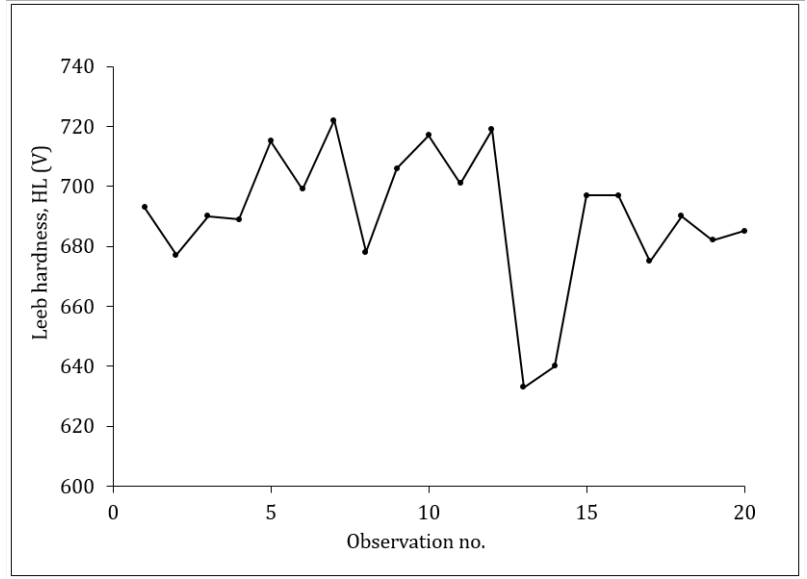

(b)

Figure 6. Recorded HLA (a) and HLv (b) values in Sample 2

To determine whether the HL values measured in both holders are influenced in the same degree by rock properties, the test statistic coefficient of variation (CoV) was considered. The $\mathrm{CoV}$ defines the percentage variation of test results in the mean value. From Table 2, the overall average CoV of the HL measurements determined in the arch and V-shaped holders were calculated as $9.98 \%$ and $9.72 \%$, respectively. This similarity between the overall averages is also confirmed in Figure 7, where a good statistical correspondence $\left(\mathrm{R}^{2}=0.75\right)$ is seen between the $\mathrm{CoV}$ values of the two holders. Therefore, it is possible to suggest that, as a general trend, the variations in the HL values determined from both holders were affected roughly by the same rock properties. Among the tested rock samples, the greatest variation in HL values was for Sample 11 (agglomerate). For this sample, the CoV values were calculated as $26.57 \%$ and $28.12 \%$ in the case of Vshaped and arch-shaped holders, respectively (Table 
2). Obviously, these relatively high values of $\mathrm{CoV}$ reflect the heterogeneity of the sample which is mainly composed of andesite pebbles embedded in a kaolinized matrix.

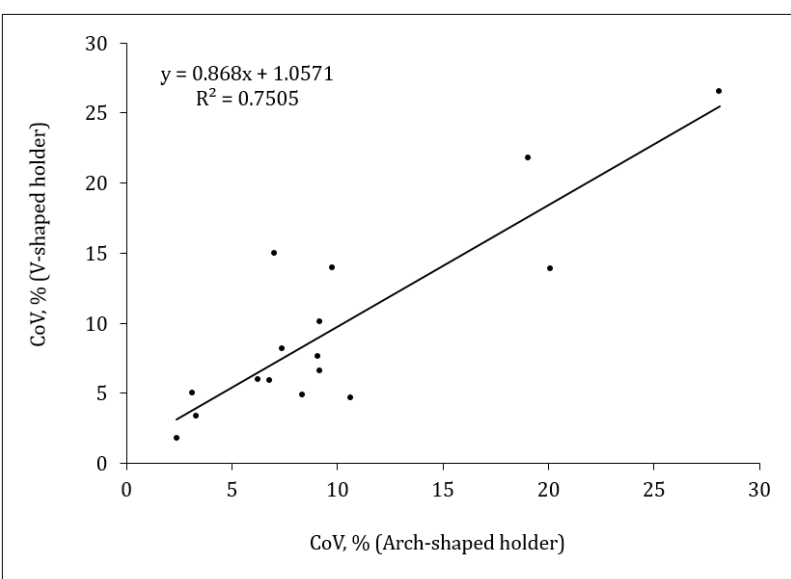

Figure 7. CoV of HL data measured in the arch and Vshaped holders

\subsection{HL values in relation to physico-mechanical rock properties}

It is known that the results of the rebound tests are generally associated with fundamental rock material properties. In this section of the study, an analysis is performed to elucidate the relations between mean HL values and some fundamental rock properties such as the uniaxial compressive strength, open porosity, and apparent density.

As seen from Figure 8, statistically significant high degrees of positive linear correlations exist between the HL values obtained in both core holders and uniaxial compressive strength (UCS):

$$
\begin{array}{rlrl}
U C S & =0.2229 H L_{A}-84.242 & \mathrm{MPa} & \left(\mathrm{R}^{2}=0.84\right) \\
U C S & =0.2343 H L_{V}-89.725 & \mathrm{MPa} & \left(\mathrm{R}^{2} \cong 0.83\right)
\end{array}
$$

This close association between the determination coefficients $\left(\mathrm{R}^{2}=0.84\right.$ and $\mathrm{R}^{2} \cong 0.83$ ) would seem to suggest that both holders can be used in practice with acceptable accuracy for UCS prediction purposes. However, it should be emphasized that the established prediction models in Equations 4 and 5 are valid only for the presently tested rock varieties. Since the measured rebound values are material specific, there is benefit in developing different prediction models for different rock classes, that should be implemented in future studies.

Relations between the measured HL values and two intrinsic rock properties, namely porosity (p) and density (d), respectively, are plotted in Figures 9 and 10. Although the plots show considerable scatter of test data, the influences of $\mathrm{p}$ and $\mathrm{d}$ appear to be roughly the same for the two holder types. As a general tendency the HL values decrease with increasing porosity whereas a reverse trend is observed in the case of density.

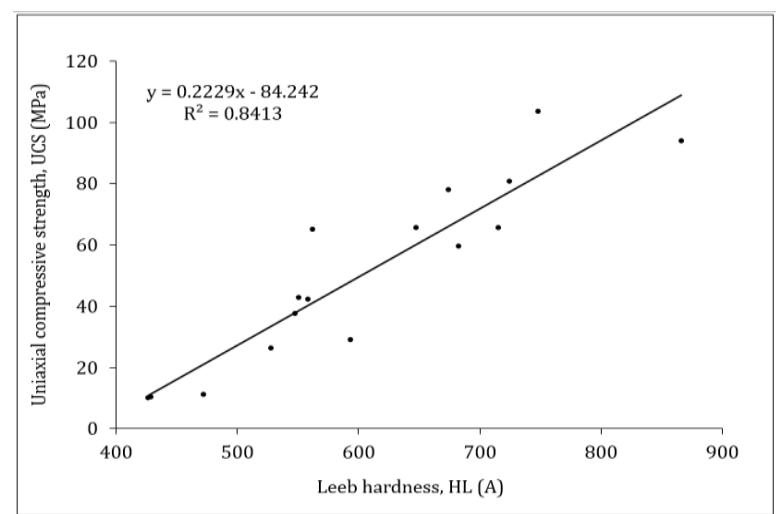

(a)

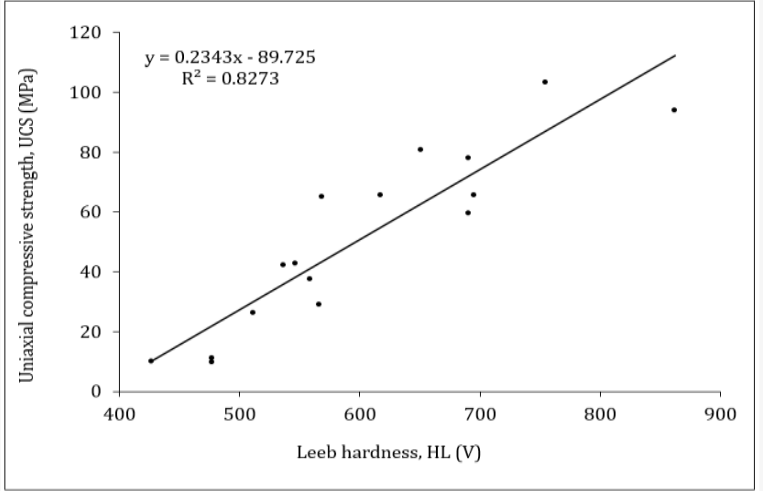

(b)

Figure 8. Relations between HL and UCS for the two holders

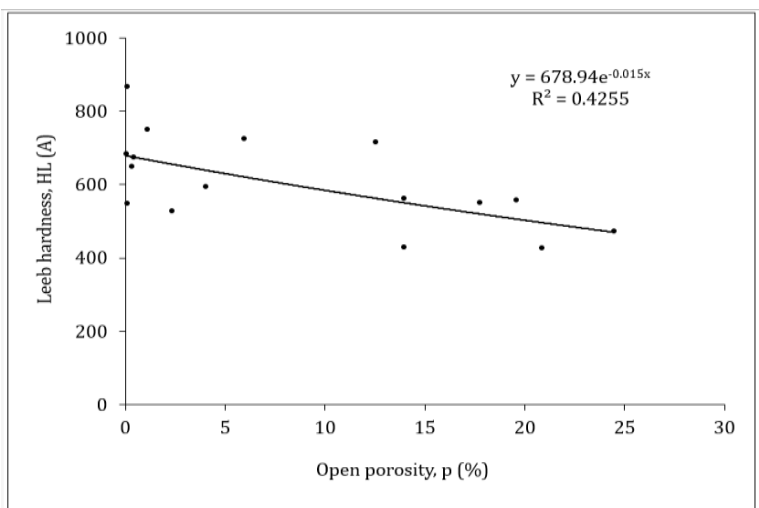

(a)

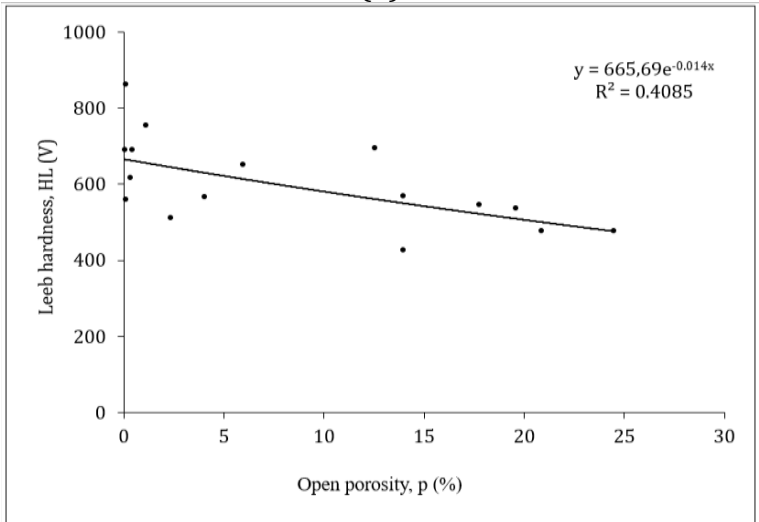

(b)

Figure 9. Relation between porosity and the measured HL values 
This might be mainly due to the fact that, depending on their magnitude, pores nearby the tested surfaces potentially absorb a certain amount of the exerted impact energy which results with lower rebound values. On the other hand, the weak-moderate correlations obtained in Figures 9 and 10 indicate that the relations between these two intrinsic rock properties and HL values are not clearly defined. This observation implies that there are other factors influencing the correlations between the considered variables. While it is a complex task to quantitatively determine the simultaneous influence of all the parameters involved, it is reasonable to state that these factors might be mainly associated with the grain size distributions of different mineral components, local structural defects arising from weathering effects, and micro-scale flaws.

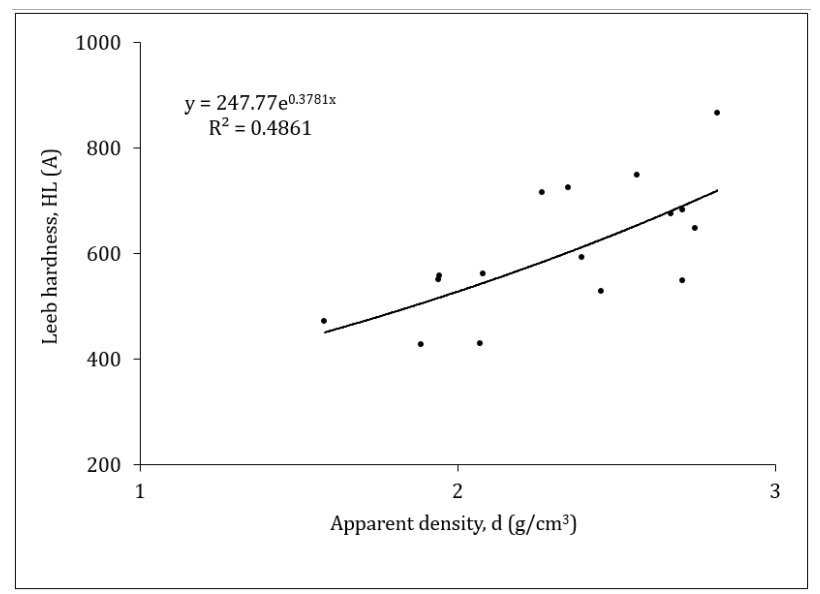

(a)

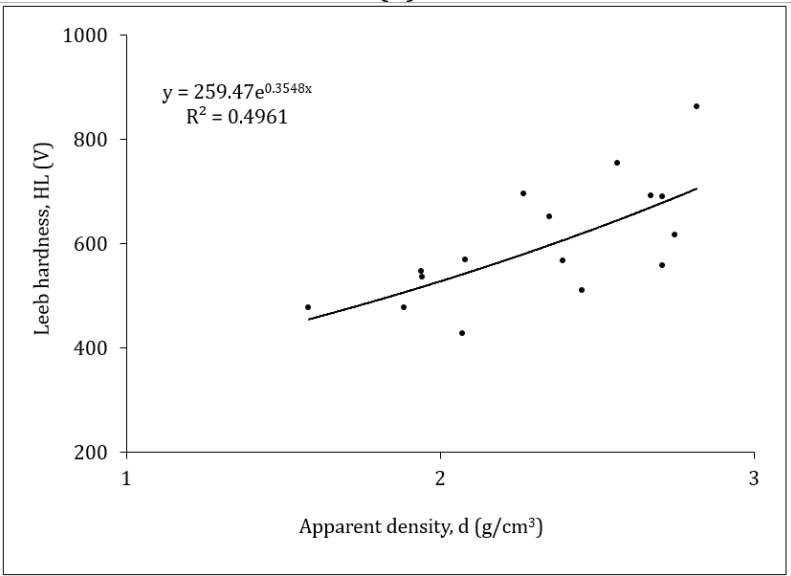

(b)

Figure 10. Relation between density and the measured HL values

\section{Conclusions}

The present study was undertaken to investigate if, and to what extent, the core holder type affects the determined Leeb hardness (LH) values of some selected rock samples. For this purpose, the HL values obtained from an arch-shaped holder $\left(\mathrm{HL}_{\mathrm{A}}\right)$ were compared with those obtained from a V-shaped holder $\left(\mathrm{HLV}_{\mathrm{V}}\right)$. The main findings are summarized in the following: (i) Statistical comparison of the mean HL values obtained in the two core holders on the same core specimens indicated a strong degree of positive linear correlation significant in the statistical sense $\left(\mathrm{R}^{2} \cong\right.$ 0.95). Despite close statistical correspondence, differences between the magnitudes of the $\mathrm{HL}_{\mathrm{A}}$ and $H_{V}$ values were not consistent and differed from one rock sample to another. The maximum difference in HL values obtained from the two holders was 74.2 units on the HL-scale, corresponding to a difference of $10.2 \%$. Compared to the minimum values, a higher statistical correspondence was observed between maximum values of $\mathrm{HL}_{\mathrm{A}}$ and $\mathrm{HL}_{\mathrm{v}}$. This observation indicated that the correlation between HL values obtained in two holders is sensitive to the degree of hardness of the tested rock material. The average coefficient of variation (CoV) values of the HL measurements determined in the arch and V-shaped holders were $9.98 \%$ and $9.72 \%$, respectively. This similarity between the magnitudes of $\mathrm{CoV}$ values suggested that the variations in the $\mathrm{HL}$ values determined in both holders were affected roughly by the same rock properties.

(ii) The UCS prediction capability of the arch-shaped holder was slightly superior to that of the V-shaped holder. However, as the test statistics indicated, the UCS of the tested rocks could reliably be estimated by employing any of the holders. The porosity and density of the tested rock samples were not significantly correlated to the HL values obtained in two holders.

Due to the lack of similar studies on the covered topic, it was not possible to compare the presently made findings with the results of any other study. Therefore, it is emphasized that further investigation should be carried out on this topic in order to check the validity of the presently reached findings for other rock types.

\section{Acknowledgments}

The authors would like to thank to Prof. Dr. A. B. Yavuz (Dokuz Eylül University, Geological Engineering Department) for kindly providing the rock samples that were used in the experiments. Thanks are also to Prof. Dr. Yaşar Kibici (Dumlupınar University, Geological Engineering Department) for his guidance in examining the thin sections and hand specimens of the samples.

\section{References}

[1] Aydin, A., Basu, A. 2005. The Schmidt hammer in rock material characterization. Engineering Geology 81, 1-14.

[2] Aoki, H., Matsukura, Y. 2007. A new technique for non-destructive field measurement of rocksurface strength: an application of Equotip hardness tester to weathering studies. Earth 
Surface Processes and Landforms 32, 17591769.

[3] Wilhelm, K., Viles, H., Burke, 0. 2016. Low impact surface hardness testing (Equotip) on porous surfaces - advances in methodology with implications for rock weathering and stone deterioration research. Earth Surface Processes and Landforms 41, 1027-1038.

[4] Proceq SA. 2007. Equotip 3 portable hardness tester, operating instructions. Switzerland.

[5] Viles, H., Goudie, A., Grab, S., Lalley, J. 2011. The use of the Schmidt hammer and Equotip for rock hardness assessment in geomorphology and heritage science: a comparative analysis. Earth Surface Processes and Landforms 36, 320-333.

[6] Hack, HRGK., Hıngıra, J., Verwaal, W. 1993. Determination of discontinuity wall strength by Equotip and ball rebound tests. International Journal of Rock Mechanics and Mining Sciences \& Geomechanical Abstracts 30, 151-155.

[7] Verwaal, W., Mulder, A. 1993. Estimating rock strength with the Equotip hardness tester. International Journal of Rock Mechanics and Mining Sciences \& Geomechanical Abstracts 30: 659-662.

[8] Alvarez Grima, M., Babuska, R. 1999. Fuzzy model for the prediction of unconfined compressive strength of rock samples. International Journal of Rock Mechanics and Mining Sciences 36, 339-349.

[9] Mol, L., Viles, HA. 2010. Geoelectric investigations into sandstone moisture regimes: Implications for rock weathering and the deterioration of San Rock Art in the Golden Gate Reserve. Geomorphology 118, 280-287.

[10] Asiri, Y., Corkum, A., El Naggar, H. 2016. Leeb hardness test for UCS estimation of sandstone. 69 th Geo Vancouver Conference, Vancouver, October 2016.

[11] Günes Yılmaz, N. 2013. The influence of testing procedures on uniaxial compressive strength prediction of carbonate rocks from Equotip hardness tester (EHT) and proposal of a new testing methodology: Hybrid dynamic hardness (HDH). Rock Mechanics and Rock Engineering 46, 95-106.

[12] Aoki, H., Matsukura, Y. 2008. Estimating the unconfined compressive strength of intact rocks from Equotip hardness. Bulletin of Engineering Geology and the Environment 67, 23-29.

[13] Kawasaki, S., Yoshida, M., Tanimoto, C., Masuya, T. 2001. The development of property evaluation method for rock materials based on the simple rebound hardness test: Investigations on the effects of test conditions and fundamental properties. Rock Mechanics - a challenge for Society, Sarkka and Eloranta (eds), Proceedings of the ISRM Regional Symposium Eurock 2001, Espoo, 4-7 June 2001, pp 103-108

[14] Meulenkamp, F., Alvarez Grima, M. 1999. Application of neural networks for the prediction of the unconfined compressive strength (UCS) from Equotip hardness. International Journal of Rock Mechanics and Mining Sciences \& Geomechanical Abstracts 36, 29-39.

[15] Van de Wall ARG, Ajalu JS. 1997. Characterization of the geotechnical properties of rock material for construction purposes. International Journal of Rock Mechanics and Mining Sciences 34, 3-4, paper No. 319.

[16] Gunes Yilmaz N, Goktan RM, Onargan T. 2015. The influence of Leeb hardness testing procedures on uniaxial compressive strength prediction of some selected decorative stones. Proceedings of the XIII National Conference With International Participation of the Open and Underwater Mining of Minerals. 1-5 September, Varna, Bulgaria.

[17] Gunsallus KL., Kulhawy, FH., O’Rourke, TD. 1984. Evaluation of Schmidt hammer rebound hardness test holders. Geotechnical Testing Journal 7, 164-166.

[18] Gunes Yilmaz, N., Goktan, RM., Yavuz, AB., Karaca, Z. 2016. Influence of rock cradle block geometry on rebound hardness. Bulletin of Engineering Geology and the Environment 75, 325-339.

[19] Turkish Standard TS EN 1936 (March 2001) Natural stone test methods-Determination of real density and apparent density, and of total and open porosity.

[20] ISRM. 2007. The complete ISRM suggested methods for rock characterization, testing and monitoring: 1974-2006. In: Ulusay R, Hudson JA (Eds) Suggested methods prepared by the ISRM commission on testing methods. Compilation arranged by the ISRM Turkish National Group, Ankara. 